\title{
Determination of Symbiotic Effectiveness of Rhizobium Strains Isolated from Food Legumes (Bean) Collected from Fez, Morocco
}

\author{
Halima Berrada1 ${ }^{1}$ Jamal Ibijbijen² and Kawtar Fikri-Benbrahim ${ }^{1 *}$ \\ ${ }^{1}$ Laboratory of Microbial Biotechnology, Sciences and Technology Faculty, Sidi Mohammed Ben Abdellah University, \\ P.O. Box 2202, Fez, Morocco. ${ }^{2}$ Environment and Soil Microbiology Unit, Faculty of Sciences, Moulay Ismail University, \\ P.O. Box 11201 Zitoune, Meknes, Morocco.
}

\begin{abstract}
This study was conducted in order to evaluate the symbiotic effectiveness of Rhizobium strains isolated from food legumes (Bean) collected from different sites in Fez city and regions (Morocco). For this purpose, 15 isolates were obtained. Seeds were inoculated with these isolates and grown in bags containing sterile soil in greenhouse under controlled plant growth conditions. $\mathbf{3 0}$ days after planting several measurements were carried out to assess nodulation, plant growth and $\mathrm{N}_{2}$ fixation. Nodule number and dry weight were determined as an indication of inoculation response; shoot and Root dry weights as an indication of growth response, and $\mathrm{N}$-uptake as an indication of nitrogen fixation effectiveness. The results of the experiment were statistically analyzed showed a statistically significant difference between the tested strains $(P<0.05)$.
\end{abstract}

Keywords: Bean, Rhizobium, $\mathrm{N}_{2}$, Fixation efficiency.

*Correspondence: kawtar.fikribenbrahim@usmba.ac.ma; 00212661216598

(Received: 09 January 2019; accepted: 06 February 2019)

Citation: Halima Berrada, Jamal Ibijbijen and Kawtar Fikri-Benbrahim, Determination of Symbiotic Effectiveness of Rhizobium Strains isolated from Food Legumes (Bean) Collected from Fez, Morocco, J Pure Appl Microbiol., 2019; 13(1):247-255 doi: 10.22207/JPAM.13.1.26

C The Author(s) 2019. Open Access. This article is distributed under the terms of the Creative Commons Attribution 4.0 International License which permits unrestricted use, sharing, distribution, and reproduction in any medium, provided you give appropriate credit to the original author(s) and the source, provide a link to the Creative Commons license, and indicate if changes were made. 


\section{INTRODUCTION}

Nitrogen is known to be an essential nutrient for plant growth, and biological nitrogen fixation is a worldwide economical and sustainable alternative for nitrogen supply to legume crops. It may reduce the expenses of chemical nitrogen fertilizers and eliminate their negative impact on the environment ${ }^{1}$.

Legumes are able to fix atmospheric nitrogen in symbiotic association with soil bacteria mainly from Rhizobiaceae Family (generically called rhizobia). Atmospheric $\mathrm{N}_{2}$ fixation by Rhizobium is one of the direct mechanisms involved in plant growth promotion and rhizobial inoculants for legumes have been used worldwide ${ }^{2}$.

Intensive farming practices that achieve high yields require chemical fertilizers, which are not only costly but may also create environmental problems. The extensive use of chemical fertilizers in agriculture is currently under debate due to environmental concern and fear for consumer's health. Consequently, there has recently been a growing level of interest in environmental friendly sustainable agricultural practices and organic farming systems ${ }^{3-4}$. Increasing and extending the role of biofertilizers such as Rhizobium would reduce the need for chemical fertilizers and decrease adverse environmental effects. Therefore, in the development and implementation of sustainable agriculture techniques, biofertilization is of great importance in alleviating environmental pollution and nature's deterioration ${ }^{5}$. Rhizobium symbiosis with legume species is of special importance, producing $50 \%$ of 175 million tones of total nitrogen biologically fixed annually worldwide ${ }^{6}$.

Indeed, inoculation of legumes with rhizobia, for the purpose of enhancing $\mathrm{N}_{2}$ fixation and yield in legume crops, is possibly the most common method of voluntary release of microbes into the environment ${ }^{7}$. Ideally, inoculation is required in the absence of compatible indigenous rhizobia, where the resident rhizobial population density is very low, or where the resident rhizobia are less infective and less effective at $\mathrm{N}_{2}$ fixation than alternative (inoculant) strain $s^{8-9}$. Soils lacking in compatible rhizobia are found in areas where indigenous related legumes are absent or where levels of $\mathrm{pH}$, osmotic stress, high temperature, and heavy metals are detrimental to rhizobial populations ${ }^{10-7}$.

The objective of this study was to assess under greenhouse conditions, nodulation and plant growth of food legumes (Bean) inoculated with different sources of rhizobial inoculums and to describe the effects of these inoculums on plant growth, shoot $\mathrm{N}$ accumulation, nodulation and $\mathrm{N}_{2}$ fixation compared with controls ( $\mathrm{T}^{-}$and $\mathrm{T}^{+}$), in order to evaluate the performance of the 15 studied strains and identify the most efficient one.

\section{MATERIALS AND METHODS \\ Plant material}

This study tested the symbiotic effectiveness of fifteen rhizobial strains with Vicia faba plants (Table 1).

These strains were screened, in a previous study, from a total of 110 root-nodulating bacteria isolated from grain and forage legumes of Fez regions and phenotypically characterized. Then, the most representative ones, on the basis of the phenotypic study, were subject to a genotypic analysis by sequencing the $16 \mathrm{~S}$ rRNA gene ${ }^{11}$. Finally, they were deposited in the Coordinated Collections of Moroccan Micro-organisms (CCMM). Culture conditions, bacterial strain and treatments Bag experiments and soil type

Experiment was carried out in a greenhouse at Sciences and Technology Faculty of Fez, using plastic bags filled with $1.5 \mathrm{~kg}$ of sterilized soil. For this investigation one type of soil was used which was sieved at $2 \mathrm{~mm}$ size and the gravel content was discarded. Soil was steam-sterilized in autoclave at $100^{\circ} \mathrm{C}$ for $1 \mathrm{~h}$ during three successive days. This is a recognized technique for soil sterilization; since some spore-forming bacteria may tolerate high temperatures. Hence, spores that may germinate on the second or third day are eliminated. Seeds were also initially surface sterilized to eliminate possible contamination by resident rhizobia.

\section{Sterilization and germination of seeds}

seeds were surface sterilized by rinsing in ethanol $95 \%(\mathrm{v} / \mathrm{v})$, soaking for $4 \mathrm{~min}$ in $\mathrm{HgCl}_{2}$ followed by three washings in sterile distilled water. The seeds were then left to imbibe in water for $4 \mathrm{~h}$. Later seeds were germinated in sterilized dishes containing sterile damp filter paper and 
Table 1. Strains, host plant and localization of the 15 strains isolated from bean in Fez and regions.

\begin{tabular}{|c|c|c|}
\hline Strains & $\begin{array}{l}\text { Host } \\
\text { plant }\end{array}$ & Sites \\
\hline B738 & Bean & Moulay Yacoub $\left(34^{\circ} 5^{\prime} 16 \mathrm{~N}, 5^{\circ} 10^{\prime} 52 \mathrm{~W}\right)$ \\
\hline B739 & Bean & Fez downtown (across from Sopriam) ( $\left.34^{\circ} 02251 \mathrm{~N} 5^{\circ} 00220 \mathrm{~W}\right)$ \\
\hline B1164 & Bean & 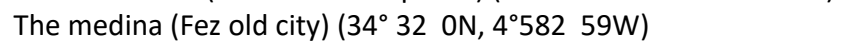 \\
\hline B740 & Bean & Annoceur $\left(33^{\circ} 40^{\prime} 0 \mathrm{~N}, 4^{\circ} 50^{\prime} 60 \mathrm{~W}\right)$ \\
\hline B1165 & Bean & Moulay Yacoub $\left(34^{\circ} 5^{\prime} 16 \mathrm{~N}, 5^{\circ} 10^{\prime} 52 \mathrm{~W}\right)$ \\
\hline B741 & Bean & Douiet $\left(34^{\circ} 2^{\prime} 60 \mathrm{~N}, 5^{\circ} 7^{\prime} \mathrm{OW}\right)$ \\
\hline B1162 & Bean & Quariat Ba Mohamed $\left(43^{\circ} 22^{\prime} 8 \mathrm{~N}, 5^{\circ} 12^{\prime} 35 \mathrm{~W}\right)$ \\
\hline B742 & Bean & The medina (Fez old city) $\left(34^{\circ} 320 \mathrm{~N}, 4^{\circ} 58259 \mathrm{~W}\right)$ \\
\hline B567 & Bean & Annoceur $\left(33^{\circ} 40^{\prime} 0 \mathrm{~N}, 4^{\circ} 50^{\prime} 60 \mathrm{~W}\right)$ \\
\hline B569 & Bean & Annoceur $\left(33^{\circ} 40^{\prime} 0 \mathrm{~N}, 4^{\circ} 50^{\prime} 60 \mathrm{~W}\right)$ \\
\hline B1163 & Bean & Immouzer road $\left(33^{\circ} 59^{\prime} 50 \mathrm{~N}, 4^{\circ} 59^{\prime} 24 \mathrm{~W}\right)$ \\
\hline B570 & Bean & Jnanate : near the old city (medina) ( $\left.34^{\circ} 320 \mathrm{~N}, 4^{\circ} 58259 \mathrm{~W}\right)$ \\
\hline B1161 & Chickpea & Douiet $\left(34^{\circ} 2^{\prime} 60 \mathrm{~N}, 5^{\circ} 7^{\prime} 0 \mathrm{~W}\right)$ \\
\hline B556 & Acacia & Sidi harazem $\left(33^{\circ} 52^{\prime} 60 \mathrm{~N}, 5^{\circ} 1^{\prime} 60 \mathrm{~W}\right)$ \\
\hline B571 & Bean & Annoceur $\left(33^{\circ} 40^{\prime} 0 \mathrm{~N}, 4^{\circ} 50^{\prime} 60 \mathrm{~W}\right)$ \\
\hline
\end{tabular}

N.B. Strains codes and abbreviations correspond to their identification in the CCMM collection.

sterile distilled water was added at intervals to keep the filter paper and germinating seeds wet. Seeds were incubated at $28^{\circ} \mathrm{C}$ for $2-3$ days until radicals were $2-3 \mathrm{~cm}$ long and root hairs appeared. After germination, three seedlings were sown in each plastic bag and inoculated with one bacterial strain culture ${ }^{12}$.

\section{Seed's Inoculation}

The inoculates were produced by growing the rhizobial strains in $250 \mathrm{ml}$ erlenmeyer flasks containing $100 \mathrm{ml}$ of yeast extract mannitol broth (YMB) and incubating at $28^{\circ} \mathrm{C}$ for 3 days on a rotary shaker at $160 \mathrm{rpm}^{13} .1 \mathrm{ml}$ (containing $10^{8}$ cells $\mathrm{ml}^{-1}$ ) of the bacterial culture at their exponentialphase of growth was inoculated just after the seedling's transfer into the bags. The treatments were as follows: (a) inoculated with rhizobia, no $\mathrm{N}$-fertilized, (b) uninoculated, $\mathrm{N}$-fertilized $\left(\mathrm{T}^{+}\right)$, and $(\mathrm{c})$ control uninoculated plants with no $\mathrm{N}$-fertilization $\left(\mathrm{T}^{-}\right)$. Treatments were arranged in a randomized block with three replicate bags and three plants per bag.

\section{Nutrient solution}

After transplanting the sterile seedling into bags, plants were surface irrigated daily with water and once weekly with $200 \mathrm{ml}$ of $\mathrm{N}$-free nutrient solution with the following composition (g/L): $\mathrm{KH}_{2} \mathrm{PO}_{4}, 0.1 ; \mathrm{CaCl}_{2}, 0.1 ; \mathrm{MgSO}_{4} .7 \mathrm{H}_{2} \mathrm{O}, 0.12$; $\mathrm{Na}_{2} \mathrm{HPO}_{4} .2 \mathrm{H}_{2} \mathrm{O}, 0.15$; ferric citrate, 0.005; and microelements solution, $1 \mathrm{ml}$. Microelements have the following composition (mg/L): $\mathrm{H}_{3} \mathrm{BO}_{4}, 2.86$; $\mathrm{MnSO}_{4} .4 \mathrm{H}_{2} \mathrm{O}, 2.03 ; \mathrm{ZnSO}_{4} .7 \mathrm{H}_{2} \mathrm{O}, 0.22 ; \mathrm{CuSO}_{4} .5 \mathrm{H}_{2} \mathrm{O}$, $0.08 ; \mathrm{Na}_{2} \mathrm{MoO}_{4} .2 \mathrm{H}_{2} \mathrm{O}, 0.14$. The $\mathrm{pH}$ of the solution was adjusted to 6.8 and it was sterilized $20 \mathrm{~min}$ at $121^{\circ} \mathrm{C}^{14}$.

In the case of $\mathrm{N}$-fertilized treatments, plants were fertilized with the $\mathrm{N}$-free nutrient solution supplemented with ( $3 \mathrm{mg}$ of $\mathrm{N}$ as $\left.\mathrm{KNO}_{3}\right)^{15}$. Determination of Nitrogen fixation

After a month, each plant was harvested then the root and shoot systems were weighted. Immediately, the root systems were washed gently under tap water. Plant's shoot and root systems were let to dry at $90^{\circ} \mathrm{C}$ for more than $48 \mathrm{~h}$ in oven and then weighed. Nodules from each individual root were collected, counted and the air-dry fresh weight of nodules was estimated. Nodules were also oven-dried at $90^{\circ} \mathrm{C}$ for $48 \mathrm{~h}$, to determine their dry weight.

$\mathrm{N}$ concentration was analyzed using the Kjeldahl method and $\mathrm{N}$ content (Shoot dry weight $\times \mathrm{N}$ concentration)/100 per plant and the $\mathrm{N}$ fixed (Plant $\mathrm{N}$ content in inoculated pots - plant $\mathrm{N}$ content in uninoculated pots) were calculated ${ }^{16}$. Efficiency of symbiosis was calculated by comparing the plant's yield when inoculated by the tested strain with a $\mathrm{N}$ fertilized control (Shoot dry weight in inoculated pots/Shoot dry weight 
in $\mathrm{N}$ fertilized plants)'100. Then nitrogen fixing efficiency have been classified as ineffective $<35 \%$, moderately effective $35-50 \%$, effective $50-80 \%$ and highly effective $>80 \%{ }^{17}$.

\section{Statistical Analysis}

All the parameters measured for the evaluation of the symbiotic efficiency tests were subjected to statistical analysis of variance using the Statgraphics software and the ANOVA test for average's comparison using the Low Significance Difference test (LSD) at $5 \%$ level.

\section{RESULTS AND DISCUSSION}

\section{Analysis of the bean plant's nodulation}

The results reported in Fig. 1 and Table 2 shows that the bean plants could be nodulated by all the tested isolates even those isolated from other host plants, like in the case for both strains B1161 and B556 respectively isolated from chickpea and acacia.
Examination of the entire plant's root system after 4 weeks of culture (branching stage) showed significant variability of nodule's distribution.

Nodules (5 to $7 \mathrm{~mm}$ or more) were located mostly below the flange while smaller different nodules were denser on lateral roots. Similar findings have been reported by El Hilali et al. ${ }^{18}$ during the inoculation tests for lupin and by Fitouri et al. ${ }^{19}$ during the inoculation tests for Sulla (Sulla coronarium L.) by different rhizobial strains.

The analysis of variance of the nodule number showed a statistically significant difference between the tested strains $(P<0.05)$. In general a wide variability of the strain's infective capacity was demonstrated (Figure 1a). Even if the inoculation of plants by various strains was performed with the same concentration which is approximately $10^{8} \mathrm{UFC} / \mathrm{ml}$, the mean number of nodules formed by plants varied between 76 and 248 nodules.

(a)

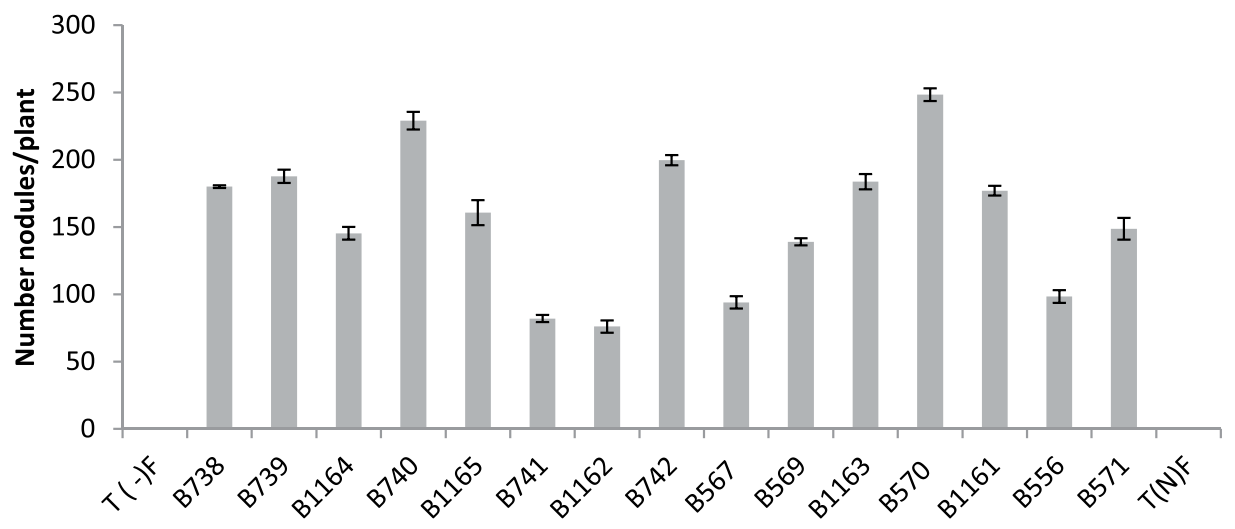

(b)

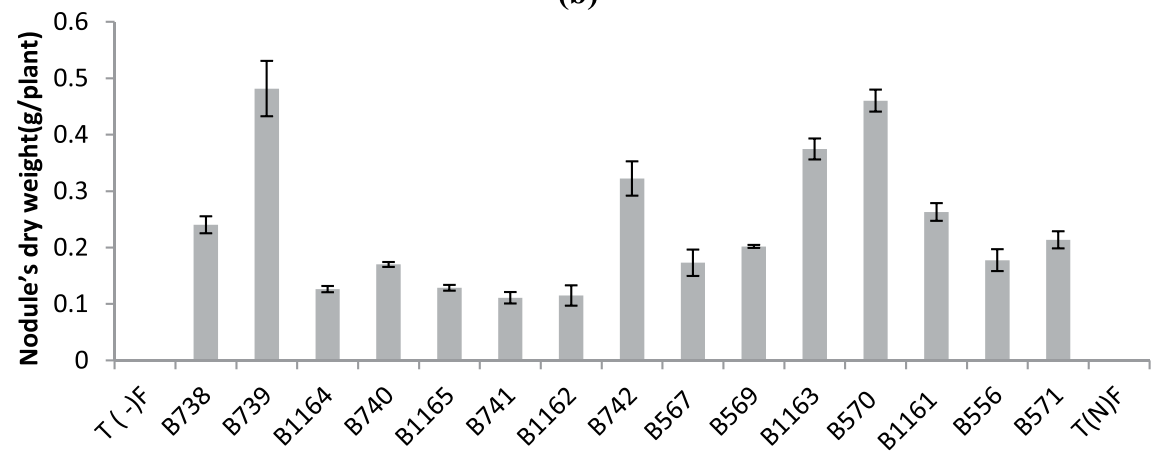

Fig. 1. Nodule's number (a), nodule's dry weight (b) of bean inoculated with different strains of Rhizobium obtained from nodules isolated from plants grown in different Fez regions. All data represent the mean \pm SD of 3 replicates.

Journal of Pure and Applied Microbiology 
Table 2. Effect of inoculation with different rhizobial strains on bean's growth, nodulation and nitrogen fixation

\begin{tabular}{|c|c|c|c|c|c|c|c|c|}
\hline Strains & Nod. Ner & $\begin{array}{c}\text { NDW } \\
\text { (g/plante) }\end{array}$ & $\begin{array}{c}\text { SDW } \\
\text { (g/plante) }\end{array}$ & N (\%) & $\begin{array}{c}\mathrm{Nc} \\
\text { (g/plante) }\end{array}$ & $\begin{array}{c}\mathrm{NF} \\
\text { (g/plante) }\end{array}$ & NFE (\%) & $\begin{array}{l}\text { Classif- } \\
\text { ication of } \\
\text { efficiency }\end{array}$ \\
\hline $\mathrm{T}(-)_{\mathrm{F}}$ & $0 \pm 00$ & $0 \pm 00$ & $6,74 \pm 0,54$ & $2,65 \pm 0.17$ & $0,17 \pm 0,01$ & - & - & - \\
\hline B738 & $180 \pm 1$ & $0,24 \pm 0.015$ & $9,81 \pm 0.49$ & $2,54 \pm 0,15$ & $0,24 \pm 0,02$ & $0,07 \pm 0,02$ & $100,3 \pm 9,07$ & VE \\
\hline B739 & $187,66 \pm 4,93$ & $0,48 \pm 0,049$ & $8,05 \pm 0,64$ & $2,77 \pm 0,36$ & $0,22 \pm 0,01$ & $0,04 \pm 0,02$ & $82 \pm 6,24$ & VE \\
\hline B1164 & $145,33 \pm 4,72$ & $0,12 \pm 0,005$ & $9,92 \pm 0,96$ & $2,94 \pm 0,13$ & $0,29 \pm 0,04$ & $0,11 \pm 0,04$ & $100,6 \pm 9,71$ & VE \\
\hline B740 & $229 \pm 6,55$ & $0,17 \pm 0,004$ & $12,91 \pm 1,06$ & $2,42 \pm 0,25$ & $0,33 \pm 0,02$ & $0,16 \pm 0,02$ & $131 \pm 5,56$ & VE \\
\hline B1165 & $160,66 \pm 9,29$ & $0,12 \pm 0,005$ & $8,62 \pm 1,41$ & $2,99 \pm 0,47$ & $0,25 \pm 0,02$ & $0,07 \pm 0,02$ & $87,3 \pm 10,96$ & VE \\
\hline B741 & $82 \pm 2,64$ & $0,11 \pm 0,010$ & $9,25 \pm 1,61$ & $2,98 \pm 0,36$ & $0,27 \pm 0,01$ & $0,09 \pm 0,01$ & $93,3 \pm 12,58$ & VE \\
\hline B1162 & $76 \pm 4,58$ & $0,11 \pm 0,018$ & $9,01 \pm 0,82$ & $289 \pm 0,21$ & $0,25 \pm 0,01$ & $0,08 \pm 0,005$ & $91,6 \pm 4,16$ & VE \\
\hline B742 & $199,66 \pm 3,78$ & $0,32 \pm 0,030$ & $8,86 \pm 1,31$ & $2,85 \pm 0,28$ & $0,25 \pm 0,01$ & $0,07 \pm 0,01$ & $90 \pm 13,22$ & VE \\
\hline B567 & $94 \pm 4,58$ & $0,17 \pm 0,023$ & $9,92 \pm 0,64$ & $2,81 \pm 0,06$ & $0,27 \pm 0,01$ & $0,10 \pm 0,02$ & $98,6 \pm 10,01$ & VE \\
\hline B569 & $139 \pm 2,64$ & $0,20 \pm 0,002$ & $9,77 \pm 1,09$ & $3,08 \pm 0,33$ & $0,29 \pm 0,003$ & $0,12 \pm 0,005$ & $99,3 \pm 9,50$ & VE \\
\hline B1163 & $183,66 \pm 5,68$ & $0,37 \pm 0,018$ & $8,95 \pm 0,84$ & $3,05 \pm 0,74$ & $0,27 \pm 0,08$ & $0,09 \pm 0,09$ & $91 \pm 11,53$ & VE \\
\hline B570 & $248,33 \pm 4,72$ & $0,46 \pm 0,019$ & $9,18 \pm 1,23$ & $2,82 \pm 0,48$ & $0,25 \pm 0,03$ & $0,08 \pm 0,04$ & $93,3 \pm 10,40$ & VE \\
\hline B1161 & $177 \pm 3,60$ & $0,26 \pm 0,015$ & $9,67 \pm 1,51$ & $2,62 \pm 0,47$ & $0,24 \pm 0,01$ & $0,07 \pm 0,02$ & $98,3 \pm 13,65$ & VE \\
\hline B556 & $98,33 \pm 4,72$ & $0,17 \pm 0,019$ & $5,97 \pm 1,34$ & $3,09 \pm 0,74$ & $0,17 \pm 0,01$ & $0,004 \pm 0,002$ & $60,6 \pm 11,01$ & $E$ \\
\hline B571 & $148,66 \pm 8,08$ & $021 \pm 0,015$ & $9,23 \pm 0,15$ & $2,48 \pm 0,44$ & $0,22 \pm 0,04$ & $0,05 \pm 0,04$ & $93,6 \pm 4,04$ & VE \\
\hline$T(N)_{F}$ & $0 \pm 00$ & $0 \pm 00$ & $9,84 \pm 0,44$ & $3,05 \pm 0,03$ & $0,30 \pm 0,01$ & - & - & - \\
\hline
\end{tabular}

The most infective strain for bean was B570 with 248 nodules formed per plant, while B1162 strain was less infective and unable to induce the formation of more than 76 nodules.

Similar results were recorded for nodule's dry weight, except for the case of B739 strain, where it was highest $(0.48 \mathrm{~g} / \mathrm{plant})$, while the number does not exceed 188 nodules (Fig.1 b). For the B740 and B1165 strains the nodule's dry weights were respectively $(0.17 \mathrm{~g} /$ plant and 0.12 $\mathrm{g}$ / plant), while nodule's numbers were 229 and 160 nodules respectively.

\section{Symbiotic performance of rhizobial strains in Bean}

Since no study of Bean inoculation has been reported in the city of Fes and regions, we propose to use rhizobial strains instead of nitrogen fertilizer.

In the experiment conducted in a greenhouse; Vicia faba was inoculated with 15 strains of Rhizobium, ten belong to Rhizobium sp, two are R. leguminosarum, two are Agrobacterium $s p$. and one strain belongs to Rhizobium radiobacter (formerly Agrobacterium tumefaciens).

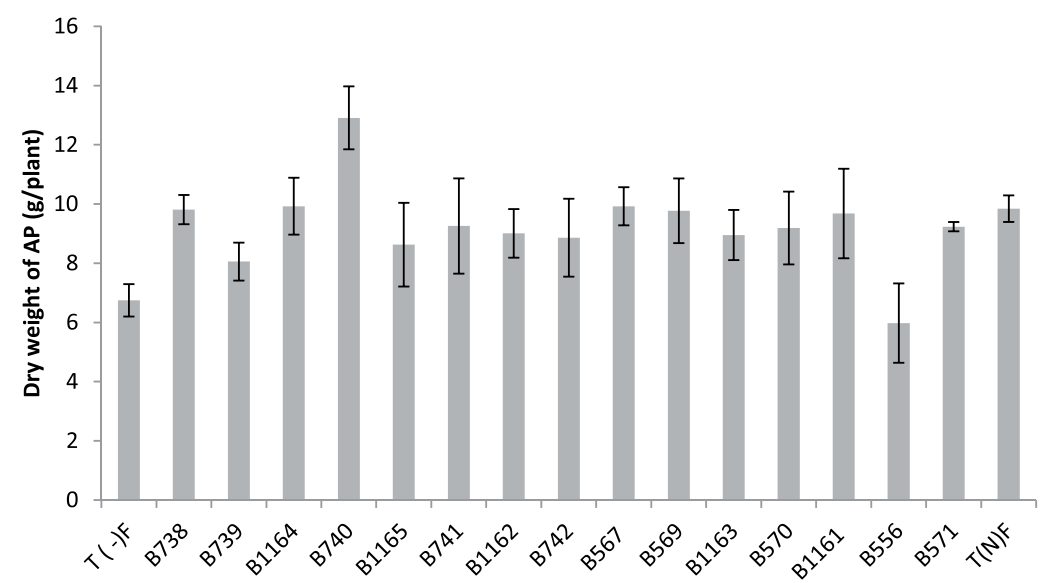

Fig. 2. Shoot Dry weight of the plants inoculated with different rhizobial strains obtained from nodules of legumes isolated from the city of Fez and its regions. All data represent the mean \pm SD of three replicates. 
Analysis of variance of the measured parameters for the selection of an efficient symbiotic association is made of the threshold of 0.05 . Factor studied (inoculation with rhizobial tested strains) has no significant effect on the nitrogen content $(\% \mathrm{~N})$ of the aerial plant's parts. While, a significant effect was observed on the other parameters measured: dry weight, total nitrogen and nitrogen fixation of the aerial parts and the relative efficiency $(P<0.05)$.

Indeed, the response of plants to inoculation showed a highly significant difference in the shoot dry weight (Fig. 2).

The results obtained for the dry weight of the aerial parts are presented in Figure 2, showing that the shoot dry weight of inoculated plants exceeded that of the control nitrogen fertilized by $\left(\mathrm{KNO}_{3}\right)$. This is the case for the strains B740, B1164 and B567 respectively with 12.90; 9.92 and 9.92 (g / plant) against 9.84g for the fertilized control.

We also note that the strain B556 gave the lowest shoot dry weight with a value of 5.98 g. These observations are not surprising, since the strain was isolated from another host plant which is acacia. This is entirely consistent with previous studies and confirms that the ability of nodulation with a Rhizobium strain in a given plant depends only on its isolated plant ${ }^{20}$ which is related to the rhizobial host specificity.
Indeed, the effectiveness of the nitrogenfixing symbiosis is dependent on symbiont in question. Rhizobial strains can fix significant amounts of nitrogen in a host, but are ineffective to fix nitrogen with another host, although nodules are formed in both cases $^{21}$. With regard to the other parameters, the most important performance in aboveground biomass, total nitrogen and fixed nitrogen is obtained with B740 strain. The symbiotic association of bean with this strain enhances the dry weight and total nitrogen of the aerial parts, by $131 \%$ and $113 \%$ respectively compared to the average for the fertilized control.

The Nitrogen content can be expressed in grams per plant ( $\mathrm{g} /$ plant) or as a percentage relative to the dry matter (\% N). This last unit is used to better compare the $\mathrm{N}$ content regardless of differences in plant growth ${ }^{22}$. The results obtained for the content of nitrogen and total nitrogen in the aerial parts are shown in Figure 3 and 4.

A positive correlation was revealed between Nitrogen content estimated by the Kjeldahl method and the total nitrogen content in shoots. Similarly, a large variability in the effectiveness of strains examined by the determination of nitrogen in the aerial part was noted.

The measurement of the total nitrogen expressed as $\mathrm{g} /$ plant showed that strain B740 has

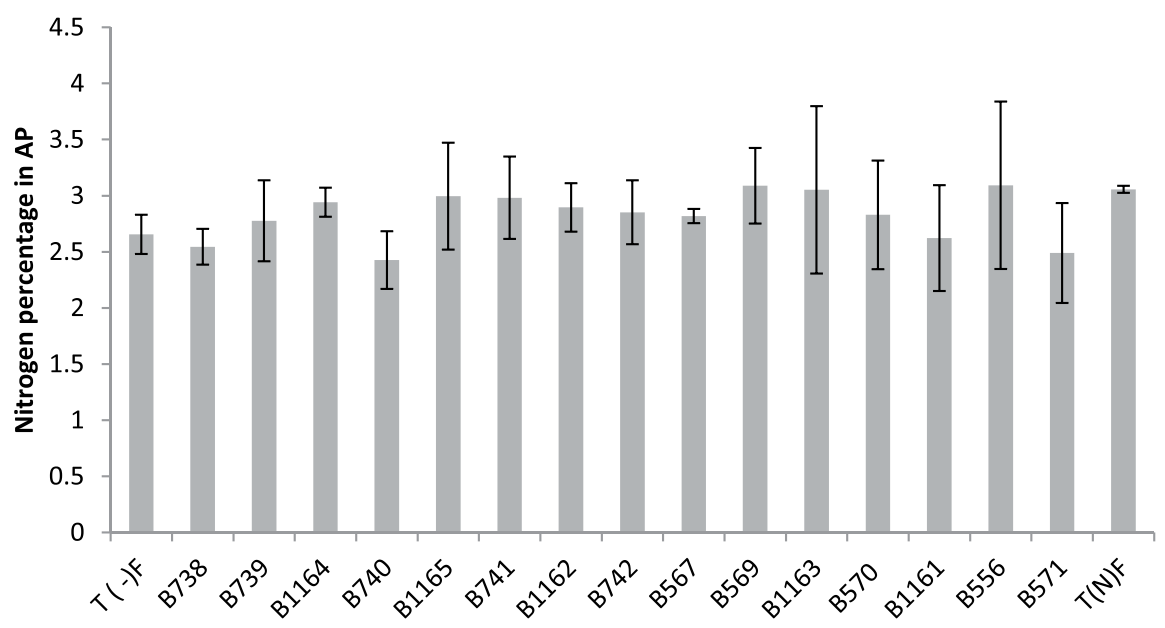

Fig. 3. Nitrogen percentage in the aerial parts of plants fertilized, non-fertilized and inoculated with different strains of Rhizobium obtained from nodules isolated from the city of Fez and its regions. All data represent the mean \pm $\mathrm{SD}$ of three replicates. 


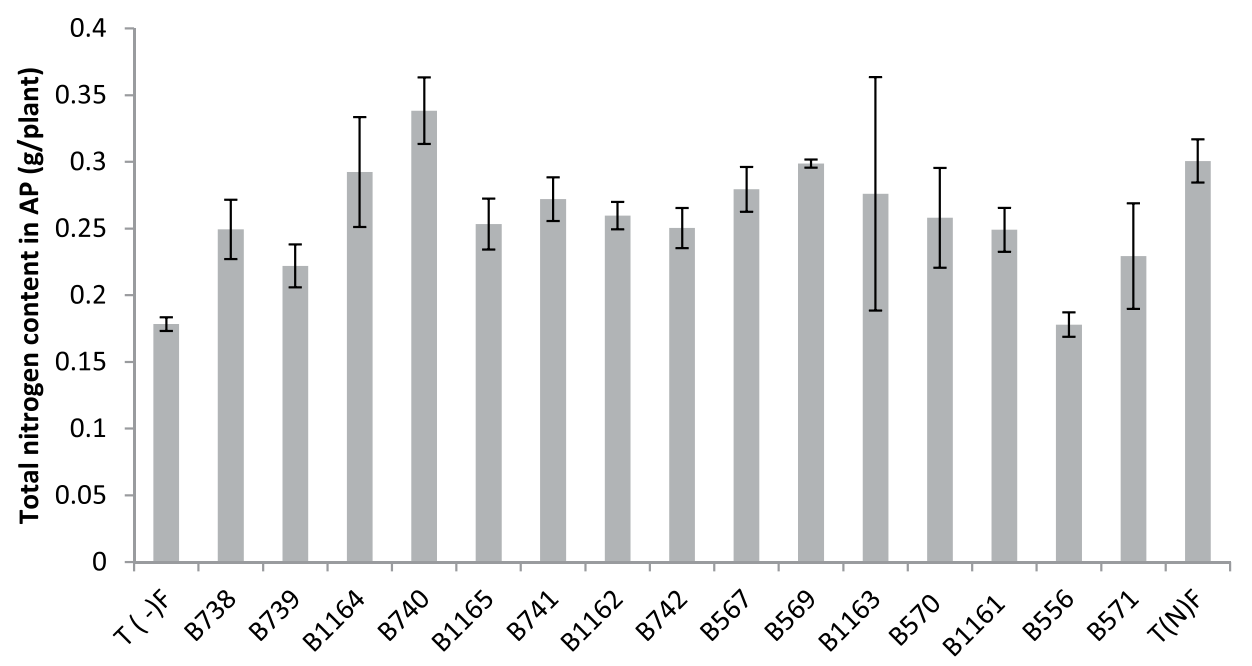

Fig. 4. Total nitrogen content in the aerial parts of broad bean plants fertilized and unfertilized inoculated with different strains of Rhizobium obtained from nodules of legumes isolated from Fez city and its regions. All data represent the mean \pm SD of 3 replicates.

the highest value $(0.34 \mathrm{~g} / \mathrm{plant})$ and significantly exceeds that of the nitrogen fertilized plant; while the strain B556 gave the lowest nitrogen content $(0.178 \mathrm{~g} /$ plant $)$, similar to the unfertilized control. For the nitrogen content, the analysis of variance for nitrogen percentage in relation to dry matter (\% $\mathrm{N})$, revealed no significant differences between the strains and comparing means has shown that the levels are very similar between different species.

Regarding the relative efficiencies obtained, they range from $61 \%$ to $131 \%$. Higher values $(131 \%, 101 \%$ and $100.33 \%$ of relative efficiency (RE)) were obtained respectively with B740, B1164 and B738 strains. In general, the strains were very efficient: with a RE values greater than $80 \%$ for $93 \%$ of the tested strains. It is important to note that the strains not isolated from bean have percentages ranging between $61 \%$ and $98 \%$, respectively for the strains isolated from acacia and chickpea (Fig. 5).

The increase in the nitrogen-fixing ability of leguminous plants inoculated with various strains of specific Rhizobium, has been highlighted by many researchers. Santos et al. ${ }^{23}$ found an increase in the nitrogen-fixing ability of soybean about $58 \%$ in response to inoculation with CPAC390 strain. Similarly, studying the diversity of rhizobia strains nodulating bean in

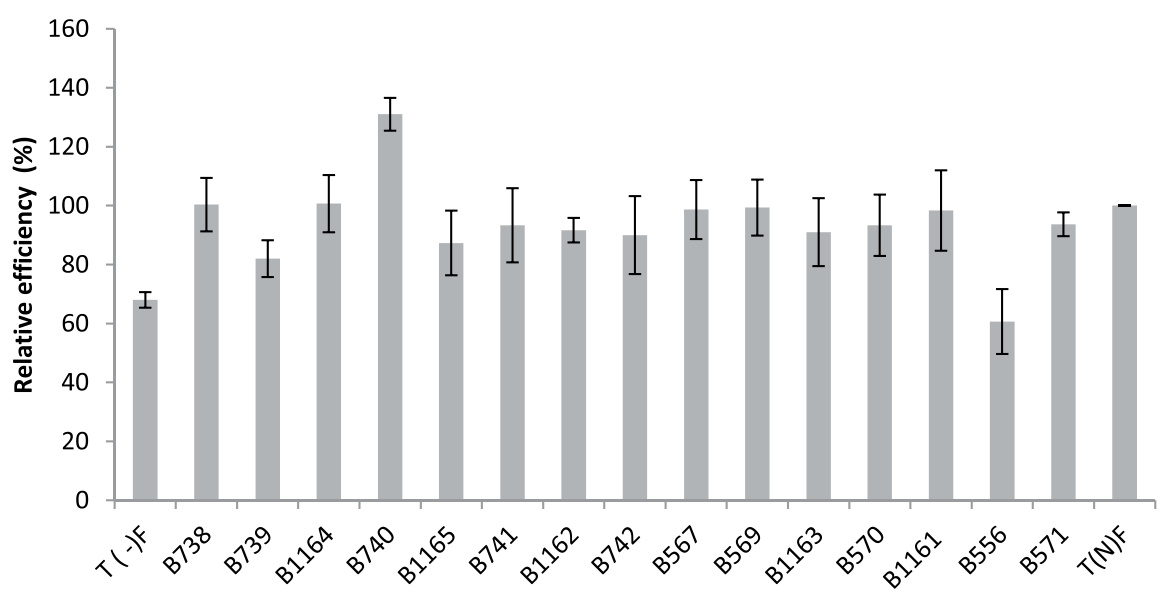

Fig. 5. Relative efficiency of the nodulating strains isolated from Fez and its regions. All data represent the mean \pm SD of 3 replicates. 
Argentina, Aguilar et $a .^{24}$ found that the yield of bean inoculated with different strains was similar to that of the fertilized plant.

Although the nodules number in plant's inoculated by B1162 strain is the lowest, it has an important relative efficiency (92\%).

This indicates that the bean consume less energy in the process of nodulation for nitrogen fixation. Similar results have been reported by Chen et al. ${ }^{25}$ and El Akhal et al. ${ }^{26}$ and showed the existence of no correlation between the number of nodules and the yield of the plant. They also found that a good performance could be obtained with a smaller number of nodule indicating that these funds were effective when a large number of nodules gives a low yield (ineffective nodules).

It should be noted that the strains belonging to Agrobacterium sp. (B1162, B1161) and Agrobacterium tumefaciens (B1163) induced a number of infective nodules of 76, 177 and 184 respectively and were very efficient with relative efficiency of $92 \%, 98 \%$ and $91 \%$ respectively.

Agrobacterium sp. is genetically related to Rhizobium species, and several authors have reported the isolation of these bacteria from nodules of different legumes. So, probably depending on soil conditions, Agrobacterium sp. behaves as a pathogen or a symbiont based on their plasmid content and their symbiotic state could be unstable under laboratory conditions.

The symbiotic instability of Agrobacterium isolates was observed by several studies $^{27-28}$ and this may be the most likely explanation for the loss of symbiotic phenotype isolates. These isolates are therefore a poor choice for the formulation of inoculants. Hungria et $a .^{29}$ reported that the strain SEMIA 4064 used as inoculant trade beans has lost its ability to fix nitrogen in greenhouse conditions and field.

These observations agree with previous finding and confirm that the inoculation programs must be directed not only to select strains of rhizobia effective, but also to select strains with genetic stability to avoid losing the plasmid Psym or genomic rearrangements ${ }^{28}$.

\section{Selecting an effective symbiosis with bean}

The combination Bean $\mathrm{x}$ rhizobial strain B740 (Rhizobium sp. EU529842.1) is significantly most effective with a relative efficiency of $131 \%$. This strain induced an increase of $131 \%$ compared to the average fertilizer control, followed by the strains B1164 and B738 with $101 \%$ and $100.33 \%$ respectively.

The symbiotic association of rhizobial strain B740 x Vicia faba can be selected as the experimental model for the field evaluation of the effect of inoculation with the bean and a rhizobial strain estimating amount of nitrogen fixed.

\section{CONCLUSION}

We conclude that the inoculation of legume seeds with reasonably large population of effective and persistent rhizobial strains constituted an evident advantage over inorganic nitrogen fertilizer which has to be applied frequently for consistent high yields. Rhizobium inoculants can be said to be a potent alternative to chemical nitrogen fertilizer as well as a renewable resource which is capable of sustaining food production with little or no purchased inputs. If properly harnessed, this technology would afford developing countries opportunity to avoid use of chemical nitrogen fertilizer which has been incriminated in most aquatic and terrestrial pollution problems.

\section{ACKNOWLEDGEMENTS}

The authors gratefully acknowledge Mr. M. Fadil who helped in the data analysis.

\section{CONFLICT OF INTEREST}

The author declares that there are no conflict of interest.

\section{REFERENCES}

1. Straliotto R, Teixeira MG, Mercante FM. Fixanтo biolq gica de nitrog nnio. pp. 121-153. In: Aidar H, Kluthcouski J, Stone LF Ed. Produnto do feijoeiro-comum em vב rzeas tropicais. Santo Antפnio de Goiבs: Embrapa Arroz e FeijTo, 2002.

2. Anandham R, Sridarb R, Nalayini P, Poonguzhali S, Madhaiyan M, Tongmin SA. Potential for plant growth promotion in groundnut (Arachis hypogaea L.) cV. ALR-2 by co-inoculation of sulfur-oxidizing bacteria and Rhizobium. Microb Res., 2007; 162: 139-153.

3. Rigby $D$, Caceres $D$. Organic farming and the sustainability of agricultural systems. Agric. Sys., 2007; 68: 21-40.

4. Lee JY, Song SH. Evaluation of groundwater quality in coastal areas: implications for sustainable agriculture. Env. Geol., 2007; 52: 1231-1242.

5. Elkoca E F, Kantar, Fiahin F. Influence of Nitrogen Fixing and Phosphorus Solu-bilizing Bacteria on the 
Nodulation, Plant Growth, Yield of Chickpea. J. Plant Nut., 2008; 31: 157-171.

6. Sar'oulu G, "znelik S, Kaymaz S. Selection of effective nodosity bacteria (Rhizobium leguminosarum biovar. viceae) from lentil grown in Elazip. Turkish J. Agric. Forestry, 1993; 17: 569-573.

7. Catroux G, Hartmann A, Revelin C. Trends in rhizobial inoculants production and use. Plant and Soil, 2001; 230: 21-30.

8. Brockwell J, Bottomley PJ, Thies JE. Manipulation of rhizobia micro ora for improving productivity and soil fertility: a critical assessment. Plant and Soil, 1995; 174: $143-180$

9. Giller KE, Cadisch G. Future bene ts from biological nitrogen xation: An ecological approach to agriculture. Plant and Soil, 1995; 174: 255-277.

10. Amarger N.1988. The microbial aspects of Faba bean culture. pp. 173-178. In Beck DP, Materon LA (Eds.), Nitrogen Fixation by Legumes in Mediterranean Agriculture. Martinus Nijhoff, Dordrecht.

11. Berrada H, Nouioui I, Iraqui Houssaini M, El Ghachtouli N, Gtari M, Fikri Benbrahim K. Phenotypic and genotypic characterizations of rhizobia isolated from root nodules of multiple legume species native of Fez, Morocco. Afr. J. Microbiol. Res., 2012; 6(25): 53145324.

12. Somasegaran $\mathrm{P}$, Hoben HJ. Methods in legumeRhizobium technology, pp:128-138. University of Hawaii, Honolulu, 1985.

13. Prevost D, Bordeleau LM, Antoun H. Symbiotic effectiveness of indigenous arctic rhizobia on a temperate forage legume: Sainfoin (Onobrychis viciifolia). Plant and Soil, 1987b; 104: 63-69.

14. Fahraeus G. J. Gen. Microbiol., 1957; 16: 374-381.

15. Keneni A, Assefa F, Prabu PC. Chara-cterization of Acid and Salt Tolerant Rhizobial Strains Isolated from Faba Bean Fields of Wollo, Northern Ethiopia. J. Agr. Sci. Tech., 2010; 12: 365-376.

16. Yaman M, Cinsoy AS. Determination of the most effective Rhizobium strain (Rhizobium japonicum L.) in soybean. J. Aegean Agric. Res. Institute, 1996; 6:84-96.

17. Purcino HMA, Festin P M, Elkan GH. Identification of Effective Strains of Bradyrhizobium for Archis pintoi. Trop. Agric., 2000; 77: 226-231.

18. El Hilali I. La symbiose Rhizobium-Lupin: Biodiversit' des microsymbiotes et mise en 'vidence d'une multiinfection nodulaire chez Lupinus luteeus. Thuse de doctorat de I'Universit' Mohammed V Agdal Rabat. Maroc, 2006.
19. Fitouri DS. Diversit's Ph'notypique et Mol'culaire des Microsymbiotes du Sulla du nord (Hedysarum coronarium L.) et s'lection de souches rhizobiales efficientes. Thuse de doctorat en sciences agronomique. Institut National Agro-nomique de Tunisie. Universit' de Carthage, 2011.

20. Diagne O. Etudes priliminaires sur quatre arbres fixateurs d'azote. Revue S'n'ga-laise des Recherches Agricoles et Hali-eutiques Vol 1(1), 1988.

21. Sarasin G. Biotechnologie des symbioses racinaires en restauration 'cologique des 'cosystumes d'grad's $N$ Madagascar. M'moire pr'sent' $\mathrm{k}$ la Facult' des 'tudes sup'rieures de l'Universit' Laval, 2011

22. Diouf D. Etude du m'tabolisme azot' chez quelques Acacias tropicaux fixateurs d'azote. M'moire pr'sent ${ }^{\prime} \mathrm{K}$ la Facultı des Sciences et Techniques, Universit' Cheikh Anta Diop Dakar, 1995.

23. Santos M A, Vargas A T, Hungria M. Characterization of soybean Bradyrhizobium strains adapted to the Brazilian savannas. FEMS Microbiol., 1999; 30: 261272.

24. Aguilar OM, Lๆpez MV, Riccillo PM. The diversity of rhizobia nodulating beans in Northwest Argentina as a source of more efficient inoculant strains. J. Biotech., 2001; 91:181-188.

25. Chen WM, Moulin L, Bontemps C, Vandamme $P$, Bena $G$, Boivin-Masson C. Legume symbiotic nitrogen fixation by beta-proteobacteria is widespread in nature. J. Bact., 2003; 185: 7266-7272.

26. El Akhal MR. Diversit' des rhizobiums nodulant l'arachide (Arachis hypogaea L.) au Maroc et l'effet de la salinit' sur le couple symbiotique. Thuse de doctorat de l'Universit' abdelmalek essaadi, Facult' des Sciences et Techniques- Tanger, Maroc, 2008.

27. De Lajudie P, Willems A, Nick G, Mohamed SH, Torck U, Coopman R, Filali-Maltouf A, Kersters K, Dreyfus B, Lindstrom K, Gillis M. Agrobacterium bv.1 strains isolated from nodules of tropical legumes. System Appl. Microb., 1999; 22: 119-132.

28. Shamseldin A, Vinuesa, P, Thierfelder H, Werner D. Rhizobium etli and Rhizobium gallicum nodulate Phaseolus vulgaris in Egyptian Soils and display cultivar-dependent symbiotic efficiency. Symbiosis, 2005; 38: 145-161.

29. Hungria M, Araujo RS. Relato da V1 reuniao de laboratorios para recomendacaode estirps de Rhizobium et Bradyrhizobium, pp. 476-489. In: Microbiologia da Sola Desafios Para O Seculo xx1. M. Hungria, E.L. Balota, A. Colozzi-Filho And D.S. Andrade, eds. IAPAR/EMBRAPA-CNPSO, Londrina, Brazil, 1995. 